\title{
NPK AND SODIUM CONTENT IN SESAME UNDER SALT STRESS AND NITRATE/AMMONIUM FERTILIZATION
}

\author{
TEORES DE NPK E SÓDIO NO GERGELIM SOB ESTRESSE SALINO E \\ ADUBAÇÃO COM NITRATO/AMÔNIO
}

\section{Adaan Sudário DIAS ${ }^{1}$; Geovani Soares de LIMA²; Hans Raj GHEYI ${ }^{3}$; Reginaldo Gomes NOBRE ${ }^{4}$; Leandro de Pádua SOUZA ${ }^{1}$; Lauriane Almeida dos Anjos SOARES ${ }^{5}$; Francisco Wesley Alves PINHEIRO ${ }^{1}$}

1. Doutorando em Engenharia Agrícola, Universidade Federal de Campina Grande-UFCG, Campina Grande, PB, Brasil; 2. Professor Visitante, UFCG, Unidade Acadêmica de Ciências Agrárias, Pombal, PB, Brasil. geovanisoareslima@ gmail.com; 3. Professor Visitante,

Universidade Federal do Recôncavo da Bahia, Cruz das Almas, BA, Brasil; 4. Professor, Doutor, Universidade Federal Rural do Semiárido, UFERSA, Caraúbas, RN, Brasil; 5. Professora, Doutora, UFCG, Unidade Acadêmica de Ciências Agrárias, Pombal, PB, Brasil.

\begin{abstract}
This study aimed to evaluate the effects of saline water irrigation and fertilization with different nitrate/ammonium proportions on the contents of nitrogen $(\mathrm{N})$, phosphorus $(\mathrm{P})$, potassium $\left(\mathrm{K}^{+}\right)$and sodium $\left(\mathrm{Na}^{+}\right)$and $\mathrm{Na}^{+} / \mathrm{K}^{+}$ratio in the sesame cv. CNPA G3, through an experiment conducted in drainage lysimeters under greenhouse conditions, in eutrophic Regolithic Neosol with sandy loam texture, in the municipality of Campina Grande-PB, Brazil. Treatments were distributed in randomized blocks, in $5 \times 5$ factorial scheme, with three replicates, relative to five levels of irrigation water salinity - $\mathrm{ECW}\left(0.6 ; 1.2 ; 1.8 ; 2.4\right.$ and $\left.3.0 \mathrm{dS} \mathrm{m}^{-1}\right)$ and five nitrate/ammonium proportions - NAP (200:0, 150:50, 100:100, 50:150, 0:200 mg kg ${ }^{-1}$ of $\left.\mathrm{NO}_{3}{ }^{-} \mathrm{N}^{-} \mathrm{NH}_{4}{ }^{+}-\mathrm{N}\right)$. Increasing ECw levels caused increment in $\mathrm{Na}^{+}$contents and reduction in $\mathrm{N}, \mathrm{P}$ and $\mathrm{K}^{+}$contents in leaf and stem tissues of the sesame cv. CNPA G3. The increase in the $\mathrm{Na}^{+} / \mathrm{K}^{+}$ratio in leaves and stem of sesame under irrigation with $\mathrm{ECW}$ water up to $3.0 \mathrm{dS} \mathrm{m}^{-1}$ can be considered as a mechanism of tolerance to salt stress. There was interaction between the factors (ECw x NAP) for the N content in the leaf tissues, and its highest accumulation was obtained with ECw of $0.6 \mathrm{dS} \mathrm{m}{ }^{-1}$ and $\mathrm{NO}_{3}{ }^{-}-\mathrm{N} / \mathrm{NH}_{4}{ }^{+}-\mathrm{N}$ proportion of $200: 0 \mathrm{mg} \mathrm{kg}^{-1}$.
\end{abstract}

KEYWORDS: Sesamum indicum L.. Salt stress. Nitrogen. Tolerance.

\section{INTRODUCTION}

Sesame (Sesamum indicum L.) is the ninth most cultivated oilseed crop in the world and stands out for having a diversity of uses, such as in energetic and pharmaceutical products and in the production of bread, cookies, candies and in the manufacture of margarine, cosmetics, perfumes, medicines, lubricants, paints and insecticides (QUEIROGA et al., 2010), constituting a good option for cultivation in the semi-arid region of northeast Brazil.

In this region, the occurrence of waters with considerable amounts of salts is common, being easily found water with electrical conductivity higher than $3.0 \mathrm{dS} \mathrm{m}^{-1}$. Besides affecting water availability through the reduction of osmotic potential and accumulation of certain ions in the protoplasm, the salts cause problems of ionic toxicity, nutritional deficiencies or both (PEDROTTI et al., 2015), consequently promoting alterations in the activity of the ions in solution and in the processes of absorption, transport, assimilation and distribution (NEVES et al., 2009; SOUSA et al., 2010). Therefore, reduced $\mathrm{Na}^{+}$ absorption, associated with low $\mathrm{Na}^{+} / \mathrm{K}^{+}$ratio, has been used as an important parameter in the selection of genotypes tolerant to salt stress (WILLADINO et al., 2011).

The anthropic pressure for good-quality waters and the increasing need for agricultural production expansion worldwide cause farmers to use waters of moderate to high salinity in irrigation (NOBRE et al., 2011). Studies have indicated the sesame crop to be sensitive to salinity (RHOADES et al., 2000; SUASSUNA, 2013); however, there are reports pointing to it being moderately tolerant to salt stress (ABBASDOKHT et al., 2012; BAHRAMI; RAZMJOO, 2012). Thus, it is necessary to employ practices that aim to mitigate the deleterious effects of salts on crops.

Among the alternatives used to reduce the negative effects of high saline concentrations in irrigation water, nitrogen fertilization stands out, because various studies claim that the supply of this element not only promotes plant growth but also can reduce the stress caused by water salinity (SOARES et al., 2012; ALVES et al., 2012; NOBRE et al., 2014; LIMA et al., 2015). In the soil, nitrogen is found in the forms of ammonium and nitrate, and both can be absorbed by plants, depending on species and/or genotype (ARAÚJO et al., 2012). 
Some crops prefer to absorb $\mathrm{N}$ in the ammoniacal form, such as rice (HOLZSCHUH et al., 2011), but the exclusive absorption of ammonium causes growth reduction in some crops, due to the utilization of the produced carbohydrates for rapid assimilation of the absorbed $\mathrm{NH}_{4}{ }^{+}$, to avoid its accumulation and consequent toxicity (ROCHA et al., 2014). In contrast, the mechanism of $\mathrm{NO}_{3}{ }^{-}$ absorption occurs only in the active form, i.e., against an electrochemical gradient, which requires metabolic energy expenditure (SILVA et al., 2010).

In this context, this study aimed to evaluate the effects of saline water irrigation and fertilization with different $\mathrm{NO}_{3}{ }^{-} \mathrm{N} / \mathrm{NH}_{4}{ }^{+}-\mathrm{N}$ proportions on the contents of nitrogen $(\mathrm{N})$, phosphorus $(\mathrm{P})$, potassium $\left(\mathrm{K}^{+}\right)$and sodium $\left(\mathrm{Na}^{+}\right)$and $\mathrm{Na}^{+} / \mathrm{K}^{+}$ratio in sesame.

\section{MATERIAL AND METHODS}

The study was conducted in pots adapted as lysimeters under greenhouse conditions, at the Center of Technology and Natural Resources of the Federal University of Campina Grande (CTRN/UFCG), located in the municipality of Campina Grande, PB, Brazil (7 $15^{\prime} 18^{\prime \prime}$ S, $\left.35^{\circ} 52^{\prime} 28^{\prime \prime} \mathrm{W} ; 550 \mathrm{~m}\right)$.

The experiment was set in randomized block design, in a 5 x 5 factorial scheme, with three replicates, and the treatments resulted from the combination of two factors: five levels of irrigation water salinity - $\mathrm{ECw}(0.6 ; 1.2 ; 1.8 ; 2.4$ and 3.0 $\mathrm{dS} \mathrm{m}^{-1}$ ) associated with five proportions of nitrate$\mathrm{NO}_{3}{ }^{-}$and ammonium- $\mathrm{NH}_{4}{ }^{+}$(200:0; 150:50; 100:100; 50:150; 0:200 mg of $\mathrm{NO}_{3}^{-}-\mathrm{N} / \mathrm{NH}_{4}{ }^{+}-\mathrm{N} \mathrm{kg}^{-1}$ of soil).Water salinity levels were obtained by dissolving the salts $\mathrm{NaCl}, \mathrm{CaCl}_{2} \cdot 2 \mathrm{H}_{2} \mathrm{O}$ and $\mathrm{MgCl}_{2} \cdot 6 \mathrm{H}_{2} \mathrm{O}$, to achieve an equivalent proportion of $7: 2: 1$ of $\mathrm{Na}: \mathrm{Ca}: \mathrm{Mg}$ (prevailing ratio in water sources used for irrigation in the Northeast region).

The experiment used 20-L lysimeters with a hole at the bottom to allow drainage, attached to a 4mm-diameter drain. The tip of the drain inside the lysimeter was involved in a nonwoven geotextile (Bidim OP 30) to avoid obstruction by soil material. A plastic bottle was placed below each drain to collect the drained water and estimate water consumption by plant. The lysimeters were filled with a $0.5-\mathrm{kg}$ layer of crushed stone followed by $24.5 \mathrm{~kg}$ of eutrophic Regolithic Neosol of sandy loam texture, collected in the $0-20 \mathrm{~cm}$ layer, in the municipality of Esperança-PB, whose chemical and physico-hydraulic characteristics (Table 1) were determined according to the methodology proposed by Claessen (1997).

Table 1. Chemical and physical characteristics of the eutrophic Regolithic Neosol, used in the experiment.

\begin{tabular}{|c|c|c|c|c|c|c|c|c|c|}
\hline \multicolumn{10}{|c|}{ Chemical characteristics } \\
\hline \multirow{2}{*}{$\begin{array}{l}\mathrm{pH}\left(\mathrm{H}_{2} \mathrm{O}\right) \\
(1: 2,5)\end{array}$} & \multirow{2}{*}{$\begin{array}{l}\mathrm{OM} \\
{\text { dag } \mathrm{kg}^{-1}}\end{array}$} & \multirow{2}{*}{$\begin{array}{c}\mathrm{P} \\
\left(\mathrm{mg} \mathrm{kg}^{-1}\right) \\
\end{array}$} & $\mathrm{K}^{+}$ & $\mathrm{Na}^{+}$ & $\mathrm{Ca}^{2+}$ & $\mathrm{Mg}^{2+}$ & $\mathrm{H}^{+}+\mathrm{Al}^{3+}$ & \multirow{2}{*}{$\begin{array}{l}\text { ESP } \\
(\%)\end{array}$} & \multirow{2}{*}{$\begin{array}{l}\text { ECse } \\
\left(\mathrm{dS} \mathrm{m}^{-1}\right)\end{array}$} \\
\hline & & & \multicolumn{5}{|c|}{ 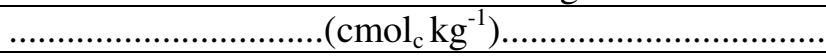 } & & \\
\hline 6.24 & 10.79 & 48.00 & 0.28 & 1.82 & 7.41 & 5.23 & 3,07 & 11.38 & 2.50 \\
\hline \multicolumn{10}{|c|}{ Physical characteristics } \\
\hline \multicolumn{3}{|c|}{ Size fraction $\left(\mathrm{g} \mathrm{kg}^{-1}\right)$} & \multirow{2}{*}{$\begin{array}{l}\text { Textural } \\
\text { class }\end{array}$} & \multicolumn{2}{|c|}{ Water content $(\mathrm{kPa})$} & \multirow[t]{2}{*}{ AW } & \multirow{2}{*}{$\begin{array}{l}\text { Total } \\
\text { porosity } \\
\mathrm{m}^{3} \mathrm{~m}^{-3}\end{array}$} & $\mathrm{AD}$ & \multirow[t]{2}{*}{ PD } \\
\hline Sand & Silt & Clay & & $\begin{array}{l}33.42 \\
\ldots \ldots \ldots \ldots \ldots\end{array}$ & $\begin{array}{l}1519.5 \\
\text { dag kg }^{-1}\end{array}$ & & & & \\
\hline 656.6 & 175.0 & 168.4 & SL & 28.84 & 10.42 & 18.42 & 0.53 & 1.27 & 2.74 \\
\hline
\end{tabular}

OM - Organic matter: Walkley-Black wet digestion; $\mathrm{Ca}^{2+}$ and $\mathrm{Mg}^{2+}$ extracted with $1 \mathrm{~mol} \mathrm{~L}^{-1} \mathrm{KCl}$ at $\mathrm{pH} 7.0 ; \mathrm{Na}^{+}$and $\mathrm{K}^{+}$extracted with 1 mol L ${ }^{-1} \mathrm{NH}_{4} \mathrm{OAc}$ at $\mathrm{pH}$ 7.0; ESP - Exchangeable sodium percentage; ECse - Electrical conductivity of the saturation extract; SL - Sandy loam; AW - Available water; AD - Apparent density; PD - Particle density.

The experiment used the sesame cultivar CNPA G3, which has medium size; a cycle between 90 and 100 days; a branched growth habit; and uniform flowering and maturation. It has one fruit/axil and cream-colored seeds. It has resistance to angular leaf spot and susceptibility to Cercospora leaf spot and Macrophomina. It is indicated for the Brazilian semi-arid region, where angular leaf spot is the main disease of the crop (LIMA et al., 2013).

Prior to sowing, the soil received irrigation sufficient to achieve field capacity, using water according to the treatments. After sowing, irrigation was performed daily at 5 p.m. by applying water to each lysimeter according to the treatment in order to elevate soil moisture to field capacity. The applied volume was determined based on the water requirements of the plants, estimated through the water balance: applied volume - volume drained in the previous irrigation.

Thinning was performed in two different periods, when sesame plants showed two and three pairs of true leaves, leaving only one plant per pot.

Basal fertilization, as recommended by Novais et al. (1991), consisted of 150 and 300 
$\mathrm{mg} \mathrm{kg}^{-1}$ of soil of $\mathrm{K}_{2} \mathrm{O}$ and $\mathrm{P}_{2} \mathrm{O}_{5}$, respectively, using potassium chloride and single superphosphate as sources. Calcium nitrate and ammonium chloride were used as sources of $\mathrm{NO}_{3}{ }^{-}$and $\mathrm{NH}_{4}{ }^{+}$, respectively. Nitrogen applications with different $\mathrm{NO}_{3}{ }^{-} / \mathrm{NH}_{4}{ }^{+}$proportions were split; one third of the dose estimated per treatment was applied at planting, and two thirds divided into three equal applications, provided via fertigation at 10-day intervals starting 25 days after sowing (DAS).

To retard the nitrification of ammoniacal $\mathrm{N}$, the nitrification inhibitor dicyandiamide (DCD) was used at dose of $10 \%$ in relation to nitrogen - $\mathrm{NH}_{4}{ }^{+}$ (TRENKEL, 1997). To meet possible deficiencies of micronutrients, plants received foliar application of Ubyfol $\left(1.0 \mathrm{~g} \mathrm{~L}^{-1}\right)$ at the beginning of the flowering stage (43 DAS) $\left(\mathrm{N}-15 \% ; \mathrm{P}_{2} \mathrm{O}_{5}-15 \% ; \mathrm{K}_{2} \mathrm{O}-\right.$ $15 \%$; Ca-1\%; Mg-1.4\%; S-2.7\%; Zn-0.5\%; B$0.05 \%$; Fe-0.5\%; Mn-0.05\%; Cu-0.5\%; Mo-0.02\%).

Treatment effects on the sesame crop, cv. CNPA G3, were evaluated based on the contents of nitrogen $(\mathrm{N})$, phosphorus $(\mathrm{P})$, potassium $\left(\mathrm{K}^{+}\right)$, sodium $\left(\mathrm{Na}^{+}\right)$and $\mathrm{Na}^{+} / \mathrm{K}^{+}$ratio in leaf and stem tissues. For the determination of $\mathrm{N}, \mathrm{P}, \mathrm{K}^{+}$and $\mathrm{Na}^{+}$, all leaves and stems of the plants were collected, according to the respective treatments. The sampled plant material was dried in a forced-air oven at 65 ${ }^{\circ} \mathrm{C}$, until constant weight. Subsequently, it was ground and subjected to chemical analysis according to the methodology recommended by Silva (1999).

The collected data were subjected to analysis of variance by $\mathrm{F}$ test and, when significant, regression analysis was applied for the factor water salinity levels and the test of comparison of means (Tukey at 0.05 probability level) for the nitrate/ammonium proportions, using the statistical software SISVAR 4.2 (FERREIRA, 2011). After verifying the normality of the residuals obtained in the present study (Table 2), exploratory analysis was conducted with the data of $\mathrm{Na}^{+}$content and $\mathrm{Na}^{+} / \mathrm{K}^{+}$ ratio in leaves and stem, which were transformed to $\sqrt{X}$ and $\sqrt{\mathrm{X}+1}$.

\section{RESULTS AND DISCUSSION}

Based on the F-test results (Table 2), there was significant effect of irrigation water salinity levels (SL) on $\mathrm{N}, \mathrm{P}, \mathrm{K}^{+}$and $\mathrm{Na}^{+}$contents and $\mathrm{Na}^{+} / \mathrm{K}^{+}$ratio in leaf and stem tissues of sesame, cv. CNPA G3. Regarding the factor nitrateN/ammonium-N proportions (NAP) and the interaction between the factors SL and NAP, there was significant effect only on $\mathrm{N}$ contents in leaf tissues.

Table2.Summary of F-test for the contents of nitrogen $(\mathrm{N})$, phosphorus $(\mathrm{P})$, potassium $\left(\mathrm{K}^{+}\right)$, sodium $\left(\mathrm{Na}^{+}\right)$and $\mathrm{Na}^{+} / \mathrm{K}^{+}$ratio in leaves and stem of sesame irrigated using water with increasing salinity and nitrate$\mathrm{N} /$ ammonium-N proportions (NAP)

\begin{tabular}{llllllllllll}
\hline \multirow{2}{*}{ Source of variation } & \multicolumn{3}{c}{$\mathrm{N}$} & \multicolumn{1}{c}{$\mathrm{P}$} & \multicolumn{3}{c}{$\mathrm{K}^{+}$} & \multicolumn{3}{c}{$\mathrm{Na}^{+}$} & \multicolumn{2}{c}{$\mathrm{Na}^{+} / \mathrm{K}^{+}$} \\
\cline { 2 - 11 } & Leaves & Stem & Leaves & Stem & Leaves & Stem & Leaves & Stem $^{1}$ & Leaves $^{2}$ & Stem $^{2}$ \\
\hline Saline levels (SL) & $*$ & $*$ & $*$ & $*$ & $* *$ & $*$ & $* *$ & $*$ & $* *$ & $*$ \\
Linear regression & $* *$ & $* *$ & $* *$ & $* *$ & $* *$ & $* *$ & $* *$ & $*$ & $* *$ & $* *$ \\
Quadratic regression & $\mathrm{ns}$ & $\mathrm{ns}$ & $\mathrm{ns}$ & $\mathrm{ns}$ & $\mathrm{ns}$ & $\mathrm{ns}$ & $\mathrm{ns}$ & $\mathrm{ns}$ & $\mathrm{ns}$ & $\mathrm{ns}$ \\
Nitrate/ammonium (NAP) & $* *$ & $\mathrm{~ns}$ & $\mathrm{~ns}$ & $\mathrm{~ns}$ & $\mathrm{~ns}$ & $\mathrm{~ns}$ & $\mathrm{~ns}$ & $\mathrm{~ns}$ & $\mathrm{~ns}$ & $\mathrm{~ns}$ \\
Interaction (SL x NAP) & $* *$ & $\mathrm{~ns}$ & $\mathrm{~ns}$ & $\mathrm{~ns}$ & $\mathrm{~ns}$ & $\mathrm{~ns}$ & $\mathrm{~ns}$ & $\mathrm{~ns}$ & $\mathrm{~ns}$ & $\mathrm{~ns}$ \\
Blocks & $\mathrm{ns}$ & $\mathrm{ns}$ & $\mathrm{ns}$ & $\mathrm{ns}$ & $\mathrm{ns}$ & $\mathrm{ns}$ & $\mathrm{ns}$ & $\mathrm{ns}$ & $\mathrm{ns}$ & $\mathrm{ns}$ \\
$\mathrm{Cv}(\%)$ & 18.94 & 14.37 & 21.80 & 14.72 & 17.05 & 19.87 & 13.74 & 13.29 & 10.90 & 11.60 \\
\hline
\end{tabular}

$\mathrm{ns},{ }^{*}, *$ respectively not significant, significant at $\mathrm{p}<0.01$ and $\mathrm{p}<0.05$. Statistical analysis performed after data transformation to $\sqrt{\mathrm{X}}$ and ${ }^{2}$ after data transformation to $\sqrt{\mathrm{X}+1}$.

According to Figure 1A, when sesame plants were subjected to different nitrateN/ammonium-N proportions, there was significant difference of the means only at the lowest salinity level $\left(0.6 \mathrm{dS} \mathrm{m}^{-1}\right)$. Plants fertilized with the nitrateN/ammonium-N proportion of 200:0 mg kg${ }^{-1}$ of soil showed the highest $\mathrm{N}$ accumulation $\left(20.46 \mathrm{~g} \mathrm{~kg}^{-1}\right)$ in the leaves, statistically differing from the other treatments, whereas plants cultivated with the other $\mathrm{NO}_{3}{ }^{-}-\mathrm{N} / \mathrm{NH}_{4}{ }^{+}-\mathrm{N}$ proportions (150:50, 100:100, $50: 150,0: 200 \mathrm{mg} \mathrm{kg}^{-1}$ ) and at the same ECw level $\left(0.6 \mathrm{dS} \mathrm{m}^{-1}\right)$ did not differ, but showed mean $\mathrm{N}_{\text {leaf }}$ contents of 12.56, 8.08, 10.94 and $9.21 \mathrm{~g} \mathrm{~kg}^{-1}$, which suggests a possible preference for nitric $\mathrm{N}$ in its accumulation by sesame plants under low salinity conditions. In addition, from $1.2 \mathrm{dS} \mathrm{m}^{-1}$ on, regardless of the NAP, there was no significant difference $(\mathrm{p}>0.05)$ between $\mathrm{N}$ contents in the leaves, which were on average equal to $9.79,9.98$, 11.18 and $10.24 \mathrm{~g} \mathrm{~kg}^{-1}$ respectively at the $\mathrm{ECw}$ levels of 1.2, 1.8, 2.4 and $3.0 \mathrm{dS} \mathrm{m}^{-1}$. Campos et al. (2016) explain that the increase of $\mathrm{N}$ supply in the 
shoots under nitrate application, compared with ammonium, occurs because nitrate does not cause toxicity to plants. On the other hand, the abovementioned authors claim that the excess of ammoniacal $\mathrm{N}$ causes damages to the root system, leading to necrosis and reduction of growth, which result in lower $\mathrm{N}$ absorption.
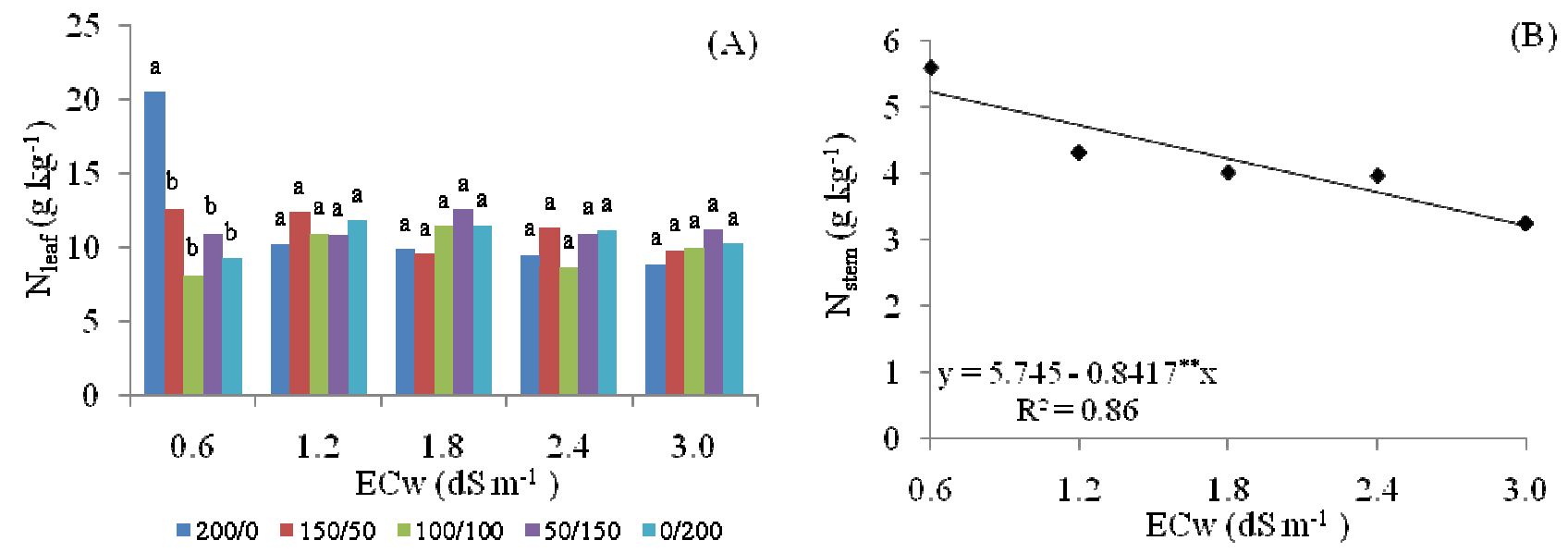

Means followed by different letters indicate difference between treatments by Tukey test $(\mathrm{p}<0.05)$

Figure 1. Nitrogen content in the leaves - $\mathrm{N}_{\text {leaf }}$ as a function of the interaction between irrigation water electrical conductivity - ECw and nitrate-N/ammonium-N proportions - NAP (A) and nitrogen content in the stem - $\mathrm{N}_{\text {stem }}$ as a function of irrigation water electrical conductivity (B)

Alves et al. (2013), studying the effect of different $\mathrm{NH}_{4}^{+}: \mathrm{NO}_{3}^{-}$proportions $\quad(100: 0 ; 75: 25$; $50: 50 ; 25: 75 ; 0: 100)$ on nutritional diagnosis of sunflower cultivated in greenhouse, also found that $\mathrm{NH}_{4}{ }^{+}: \mathrm{NO}_{3}$-ratio of $0: 100$ led to highest $\mathrm{N}$ content in the leaves $\left(21.83 \mathrm{~g} \mathrm{~kg}^{-1}\right)$ and shoots $\left(39.08 \mathrm{~g} \mathrm{~kg}^{-1}\right)$ of the seedlings. According to Lucena et al. (2012), reduction in $\mathrm{N}$ content, under salt stress conditions, as observed in the present study (Figure 1A), is possibly associated with competitive mechanisms triggered by the excess of absorption and translocation of the $\mathrm{Cl}^{-}$ion to the leaves.

Different water salinity levels negatively affected $\mathrm{N}_{\text {stem }}$ contents and, according to the regression equation (Figure 1B), there was a reduction of $14.65 \%$ in $\mathrm{N}_{\text {stem }}$ content per unit increase in $\mathrm{ECw}$, characterizing a decrease of $35.16 \%$ in $\mathrm{N}_{\text {stem }}$ content in plants under irrigation with $\mathrm{ECw}$ of $3.0 \mathrm{dS} \mathrm{m} \mathrm{m}^{-1}$, compared with those subjected to the lowest $\mathrm{ECw}$ level $\left(0.6 \mathrm{dS} \mathrm{m}^{-1}\right)$. Lucena et al. (2011), evaluating the effect of irrigation water salinity (ECW from 0.6 to $3.98 \mathrm{dS}$ $\mathrm{m}^{-1}$ ) on growth and macronutrient accumulation of Quetzali watermelon, also found as in the present study linear decrease in total $\mathrm{N}$ accumulation as the $\mathrm{ECw}$ levels increased. According to these authors, $\mathrm{N}$ accumulation can be reduced by $70 \%$ at high salinity levels, because there may be inhibition of nitrate absorption due to the $\mathrm{NO}_{3}^{-} / \mathrm{Cl}^{-}$interaction in the absorption sites or to the depolarization of the membrane by Na.

$\mathrm{P}_{\text {leaf }}$ and $\mathrm{P}_{\text {stem }}$ contents linearly decreased as the $\mathrm{ECw}$ levels increased and, based on the regression equations (Figure $2 \mathrm{~A}$ and $\mathrm{B}$ ), there were reductions of 7.09 and $8.20 \%$ with per unit increase in $\mathrm{ECw}$ in $\mathrm{P}_{\text {leaf }}$ and $\mathrm{P}_{\text {stem }}$ contents, respectively, i.e., sesame plants subjected to irrigation with water of $3.0 \mathrm{dS} \mathrm{m}^{-1}$ exhibited reductions of 0.66 and $1.06 \mathrm{~g}$ $\mathrm{kg}^{-1}$ in $\mathrm{P}_{\text {leaf }}$ and $\mathrm{P}_{\text {stem }}$ accumulation, respectively. Oliveira et al. (2011) obtained quadratic response for $\mathrm{P}$ accumulation in the leaf tissues of eggplant irrigated with saline water and grown in greenhouse; highest $\mathrm{P}$ accumulation (95.85 mg plant $^{-1}$ ) was observed at salinity of $1.59 \mathrm{dS} \mathrm{m}^{-1}$, decreasing from this point on, so that plants subjected to the highest level of salt stress $\left(4.5 \mathrm{dS} \mathrm{m}^{-1}\right)$ obtained 38.19 mg plant ${ }^{-1}$, which corresponded to a reduction of the order of $60.15 \%$. These authors also point out that $\mathrm{P}$ has important function in the composition of ATP, responsible for energy storage and transport for processes and active absorption of nutrients. This suggests that $\mathrm{P}$ deficiency during plant development may limit crop growth, a condition from which the plant no longer recovers. 

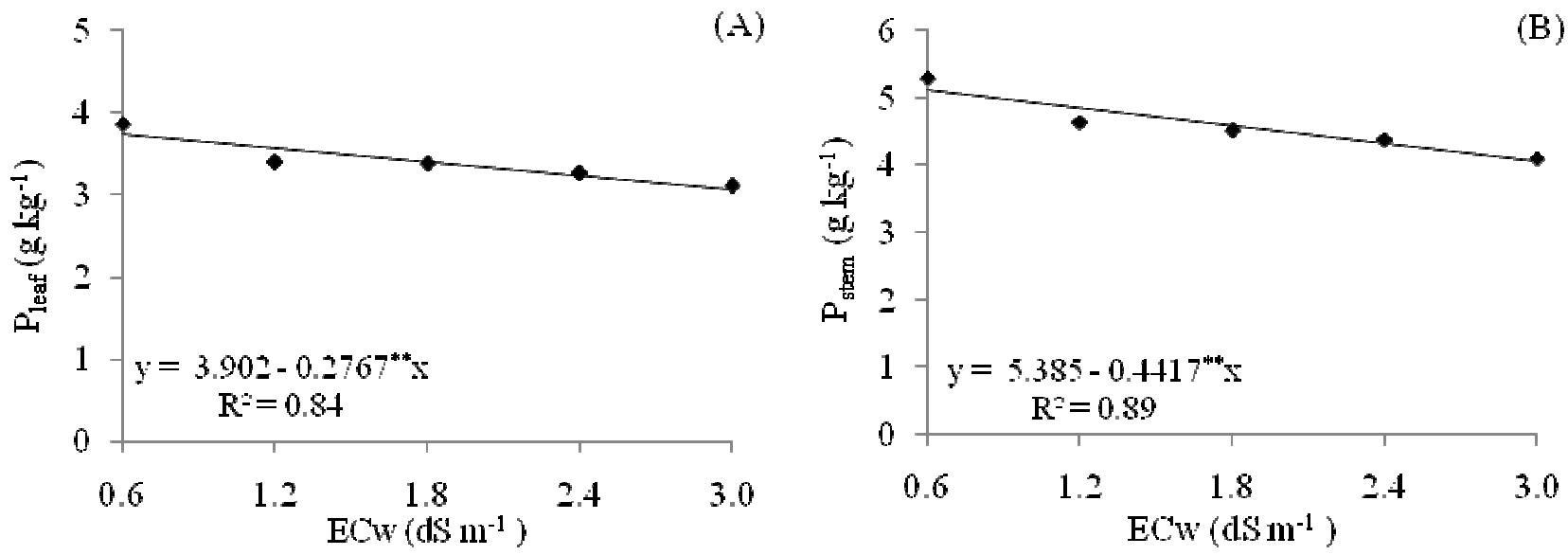

Figure 2. Phosphorus content in the leaves $-\mathrm{P}_{\text {leaf }}(\mathrm{A})$ and in the stem $-\mathrm{P}_{\text {stem }}(\mathrm{B})$ of sesame plants, cv. CNPA G3, as a function of irrigation water electrical conductivity - ECw

In general, salinity reduces $\mathrm{P}$ content in plant tissue, due to the effects of ionic force and decrease in the solubility of this mineral as the $\mathrm{NaCl}$ levels increase in the soil. The interaction between salinity and $\mathrm{P}$ content in the plants is complex and depends on species, cultivar, phenological stage, $\mathrm{P}$ content in the substrate, types of salts and salinity level (SOUSA et al., 2010).

As observed for $\mathrm{P}_{\text {leaf }}$ and $\mathrm{P}_{\text {stem }}, \mathrm{K}_{\text {leaf }}$ and $\mathrm{K}_{\text {stem }}$ contents were also significantly reduced by the increment in irrigation water salinity and, according to the regression analysis (Figure $3 \mathrm{~A}$ and $\mathrm{B}$ ), there were linear reductions of 7.77 and $6.44 \%$ in $\mathrm{K}_{\text {leaf }}$ and $\mathrm{K}_{\text {stem }}$ contents per unit increase in $\mathrm{ECw}$, which corresponded to reductions of 2.96 and $2.75 \mathrm{~g} \mathrm{~kg}^{-1}$ in $\mathrm{K}_{\text {leaf }}$ and $\mathrm{K}_{\text {stem }}$ contents, respectively, between plants subjected to the highest ECw level $\left(3.0 \mathrm{dS} \mathrm{m}^{-}\right.$ ${ }^{1}$ ) and those irrigated with $0.6 \mathrm{dS} \mathrm{m}{ }^{-1}$. Garcia et al. (2007) explain that the increase in $\mathrm{Na}^{+}$concentration in the external medium leads to reduction of $\mathrm{K}^{+}$ contents in plant tissues, because the increase in $\mathrm{Na}^{+}$ concentration in the soil solution can inhibit $\mathrm{K}^{+}$ absorption due to the competitive relationship between both monovalent cations. These authors also observed linear reductions in the contents of this macronutrient in the leaf tissues of maize plants subjected to increasing levels of irrigation water salinity.
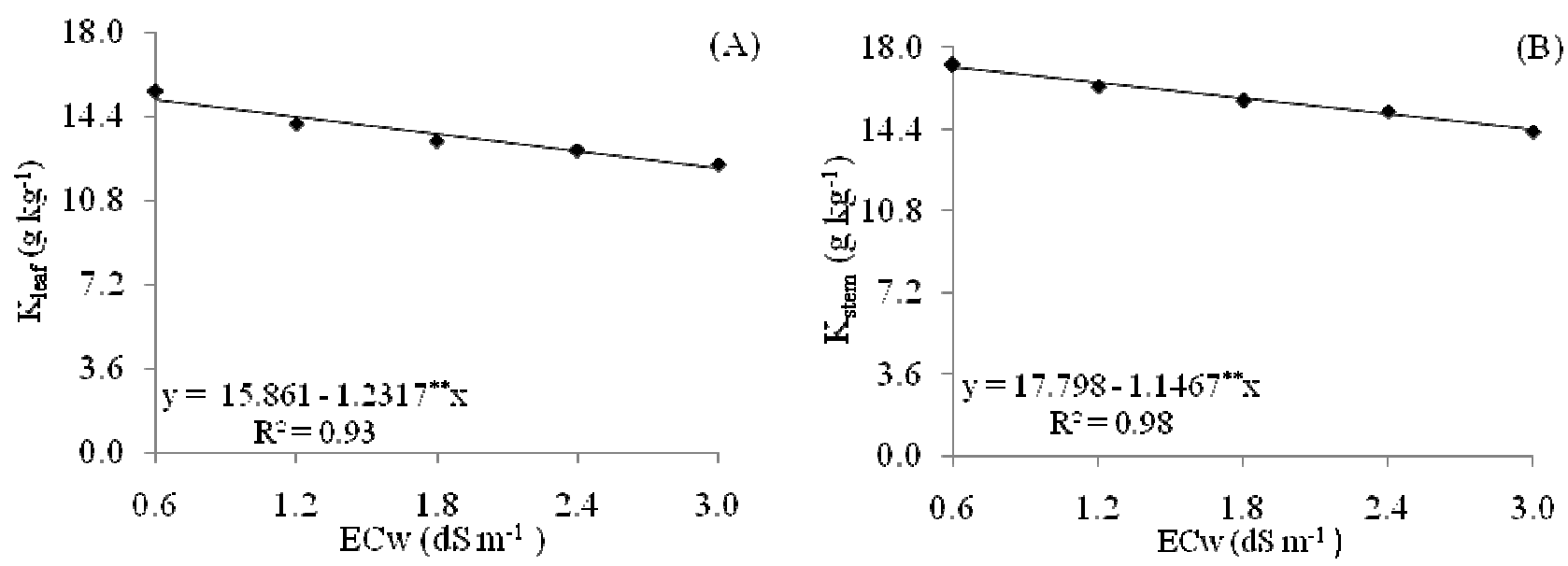

Figure 3. Potassium content in leaves $-K_{\text {leaf }}(A)$ and stem - $K_{\text {stem }}(B)$ of sesame plants, cv. CNPA G3, as a function of irrigation water electrical conductivity $-\mathrm{ECW}$

$\mathrm{Na}_{\text {leaf }}$ and $\mathrm{Na}_{\text {stem }}$ contents increased as the levels of irrigation water salinity increased and, according to the regression equations (Figure $4 \mathrm{~A}$ and B), in both tissues (leaves and stem) the increasing linear regression model showed best fit to the data. In leaf tissues, $\mathrm{Na}^{+}$accumulation reached
$3.21 \mathrm{~g} \mathrm{~kg}^{-1}$ at the end of the cycle in sesame plants irrigated with ECw of $3.0 \mathrm{dS} \mathrm{m}^{-1}$, and $0.75 \mathrm{~g} \mathrm{~kg}^{-1}$ in plants under ECw of $0.6 \mathrm{dS} \mathrm{m} \mathrm{m}^{-1}$, which represents an increment of $2.46 \mathrm{~g} \mathrm{~kg}^{-1}$ in $\mathrm{Na}_{\text {leaf }}$ content (Figure 4A). In stem tissues, there was an increment of 1.98 $\mathrm{g}$ of $\mathrm{Na}^{+} \mathrm{kg}^{-1}$ of dry matter in plants irrigated using 
water of highest $\mathrm{ECw}\left(3.0 \mathrm{dS} \mathrm{m}^{-1}\right)$, in comparison to those under the lowest ECw level $\left(0.6 \mathrm{dS} \mathrm{m}^{-1}\right)$.

Increase of $\mathrm{Na}^{+}$content in plant tissues was also reported by Silva et al. (2009), who evaluated the influence of irrigation water salinity on the accumulation of $\mathrm{Na}^{+}, \mathrm{Cl}^{-}$and $\mathrm{K}^{+}$in young jatropha plants and observed excessive $\mathrm{Na}^{+}$accumulation in leaf tissues, which was proportional to the increase in the applied doses of $\mathrm{NaCl}$.

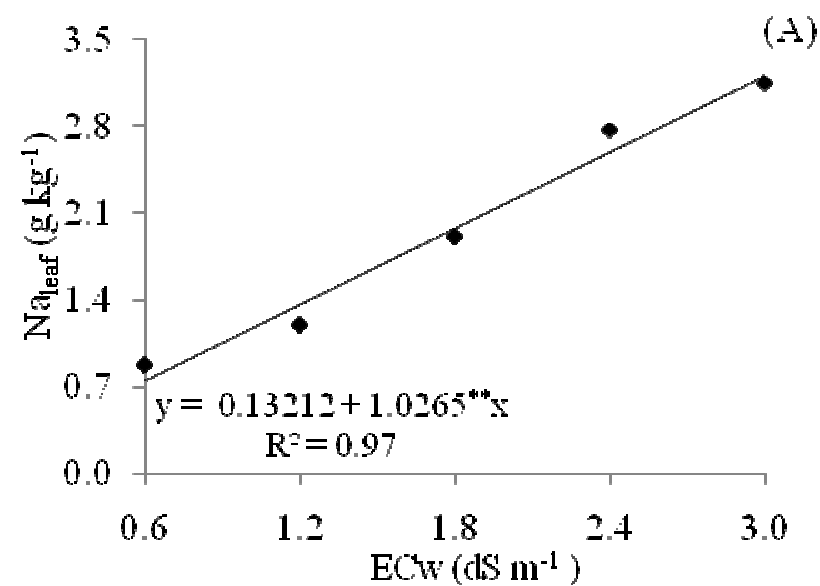

According to the data presented in Figure $4 \mathrm{~A}$ and $\mathrm{B}$, the increment in $\mathrm{Na}^{+}$accumulation was more accentuated in sesame leaf tissues (Figure 4A), compared with its stem tissues (Figure 4B). In addition, highest $\mathrm{Na}^{+}$accumulation occurred in stem tissues, which denotes the existence of a possible defense mechanism in the sesame crop (ionic compartmentalization), accumulating $\mathrm{Na}^{+}$in the stem to preserve the integrity of its photosynthetic apparatus.

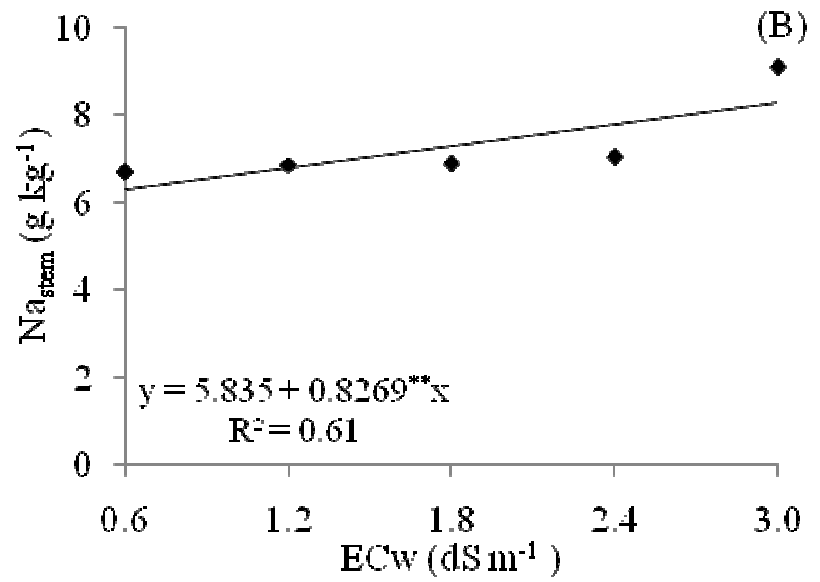

Figure4. Sodium content in leaves - $\mathrm{Na}_{\text {leaf }}(\mathrm{A})$ and stem $-\mathrm{Na}_{\text {stem }}$ (B) of sesame plants, cv. CNPA G3, as a function of irrigation water electrical conductivity - ECW

The increment in $\mathrm{Na}^{+}$content results from the time of accumulation through the transpiration rate and low mobility of this element in the plant (Nobre et al., 2013). These authors subjected castor bean to salt stress and $\mathrm{N}$ fertilization and found linear increase in $\mathrm{Na}^{+}$contents in leaves and stems, as the ECw levels increased, respectively reaching values of 185 and $581 \%$ at 120 DAS, in plants subjected to irrigation using water of $4.4 \mathrm{dS} \mathrm{m}^{-1}$, in comparison to those under $0.4 \mathrm{dS} \mathrm{m}^{-1}$. These authors also found that the highest $\mathrm{Na}^{+}$accumulation was obtained in the castor bean stem, as occurred in the present study.

The $\mathrm{Na}^{+} / \mathrm{K}^{+}$ratio was significantly affected by the different levels of irrigation water salinity, both in leaves and stems of the sesame crop, and the data fitted to a positive linear model. According to the regression equations (Figure $5 \mathrm{~A}$ and $\mathrm{B}$ ), $\mathrm{Na}^{+} / \mathrm{K}^{+}$ ratio increased by 0.21 (leaves) and 0.23 (stem) in plants subjected to ECw of $3.0 \mathrm{dS} \mathrm{m}{ }^{-1}$, compared with the control $\left(\mathrm{ECw}=0.6 \mathrm{dS} \mathrm{m} \mathrm{m}^{-1}\right)$. Additionally, $\mathrm{Na}^{+} / \mathrm{K}^{+}$ratio was higher in the stem than in the leaves, which reflects the strategy of $\mathrm{Na}^{+}$ compartmentalization in these organs by sesame plants, in order to keep the photosynthetic apparatus intact, as previously observed for $\mathrm{Na}^{+}$contents in the studied tissues (Figure 4A and B), while their $\mathrm{K}^{+}$ content decreased, as previously mentioned (Figures $3 \mathrm{~A}$ and $3 \mathrm{~B})$.

It is possible to observe that, under saline conditions, $\mathrm{K}^{+}$content, despite being reduced, were still higher than $\mathrm{Na}^{+}$content in leaf and stem tissues $\left(\mathrm{Na}^{+} / \mathrm{K}^{+}\right.$ratio lower than 1$)$. Lima et al. (2015) claimed that the $\mathrm{Na}^{+} / \mathrm{K}^{+}$ratio indicates the ability of plants to selectively absorb cationic macronutrients, especially $\mathrm{K}^{+}$, because this ratio indicates the degree of selectivity of the species in the absorption and compartmentalization of these ions in its tissues. Cruz et al. (2006) mentioned that the maintenance of low $\mathrm{Na}^{+} / \mathrm{K}^{+}$ratios is considered as an adaptive characteristic of the plants to keep their growth in saline environments, because it allows cells to perform their main functions at levels close to normal.

Sousa et al. (2012) explain that increment of $\mathrm{Na}^{+}$contents in plant tissues in detriment of the absorption of nutrients such as $\mathrm{K}^{+}$during the exposure to salt stress, as observed in the present study, is one of the main effects of this stress on plant metabolism. As found in the present study, increase in $\mathrm{Na}^{+} / \mathrm{K}^{+}$ratio due to the increment in irrigation water electrical conductivity was also observed by Garcia et al. (2007) in leaves of maize subjected to salt stress and by Lima et al. (2015) in 
leaves and stems of castor bean under saline water irrigation and $\mathrm{N}$ fertilization.
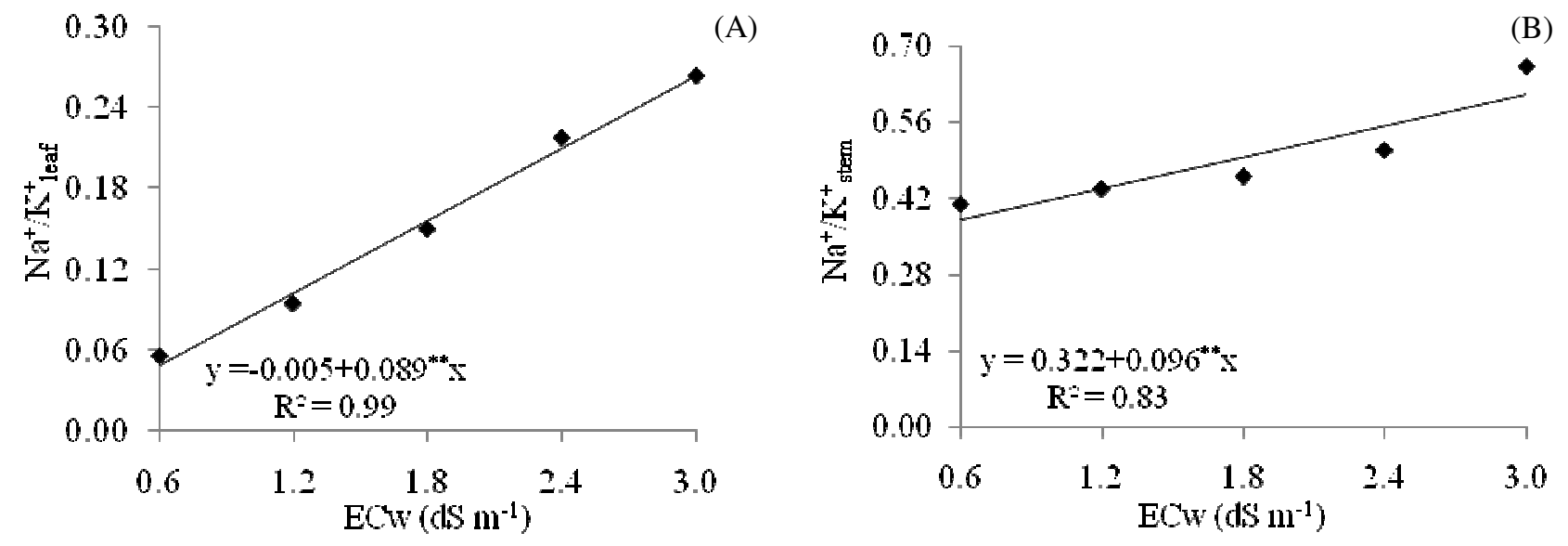

Figure 5. $\mathrm{Na}^{+} / \mathrm{K}^{+}$ratio in leaves $-\mathrm{Na}^{+} / \mathrm{K}^{+}$leaf $(\mathrm{A})$ and stem $-\mathrm{Na}^{+} / \mathrm{K}^{+}$stem $(\mathrm{B})$ of sesame, cv. CNPA G3, as a function of irrigation water electrical conductivity - $\mathrm{ECW}$

Based on the results for leaf and stem tissues, the contents of $\mathrm{N}, \mathrm{P}, \mathrm{K}^{+}$and $\mathrm{Na}^{+}$in sesame leaves, as a function of irrigation water salinity, occurred in the following sequence of magnitude: $\mathrm{N}>\mathrm{K}^{+}>\mathrm{P}>\mathrm{Na}^{+}$; in stem tissues, the sequence of accumulation was $\mathrm{K}^{+}>\mathrm{Na}^{+}>\mathrm{N}>\mathrm{P}$. Similar results were observed by Corrêa et al. (1995), who evaluated the exportation of nutrients by the sesame cv. Jori, at harvest, and concluded that, under saline conditions, $\mathrm{N}, \mathrm{P}$ and $\mathrm{K}^{+}$accumulation occurred in the following decreasing order: $\mathrm{N}>\mathrm{K}>\mathrm{P}$ in the leaves and $\mathrm{K}>\mathrm{N}>\mathrm{P}$ in the stem.

\section{CONCLUSIONS}

Increasing levels of water salinity promoted increment in $\mathrm{Na}^{+}$content and reduction in $\mathrm{N}, \mathrm{P}$ and $\mathrm{K}^{+}$contents in leaf and stem tissues of sesame, $\mathrm{cv}$. CNPA G3;
The increase in the $\mathrm{Na}^{+} / \mathrm{K}^{+}$ratio in leaves and stem of sesame under irrigation with $\mathrm{ECw}$ water up to $3.0 \mathrm{dS} \mathrm{m}^{-1}$ can be considered as a mechanism of tolerance to salt stress;

There is interaction between the factors irrigation water salinity levels and nitrate/ammonium proportions for the $\mathrm{N}$ content in leaf tissues and its highest accumulation was obtained with water salinity of $0.6 \mathrm{dS} \mathrm{m}^{-1}$ and $\mathrm{NO}_{3}^{-}$$\mathrm{N} / \mathrm{NH}_{4}{ }^{+}-\mathrm{N}$ proportion of 200:0 $\mathrm{mg} \mathrm{kg}^{-1}$.

\section{ACKNOWLEDGMENTS}

To the National Institute of Science and Technology in Salinity - INCTSal, for funding the project, and to the National Postdoctoral Program PNPD/CAPES, for providing the scholarship to the second author.

RESUMO: Objetivou-se, neste trabalho, avaliar os efeitos da irrigação com águas salinas e adubação com diferentes proporções de nitrato e amônio sobre os teores de NPK, sódio e relação Na/K no gergelim cv. CNPA G3, em experimento conduzido em lisímetros de drenagem sob condições de casa de vegetação, no Neossolo Regolítico Eutrófico, textura franco-arenosa, no município de Campina Grande, PB. Os tratamentos foram distribuídos em blocos casualizados, em esquema fatorial $5 \times 5$, com três repetições, referentes a cinco níveis de condutividade elétrica da água de irrigação CEa $\left(0,6 ; 1,2 ; 1,8 ; 2,4\right.$ e 3,0 dS m$\left.{ }^{-1}\right)$ e cinco proporções de nitrato e de amônio - PNA (200:0, 150:50, 100:100, 50:150, 0:200 mg kg ${ }^{-1}$ de N-NO${ }_{3}^{-} / \mathrm{N}_{-}-\mathrm{NH}_{4}{ }^{+}$). Níveis crescentes de CEa promoveu aumento nos teores de $\mathrm{Na}^{+}$e diminuição nos teores de N P K nos tecidos foliares e caulinar do gergelim cv. CNPA G3; o aumento na relação $\mathrm{Na}^{+} / \mathrm{K}^{+}$nas folhas e caule do gergelim sob irrigação com água de CEa até $3.0 \mathrm{dS} \mathrm{m}^{-1}$ pode ser considerado como mecanismo de tolerância ao estresse salino; houve interação entre os fatores (CEa x PNA) para teor de nitrogênio nos tecidos das folhas, sendo o maior acúmulo obtido com CEa de $0,6 \mathrm{dSm}^{-1}$ e proporções de 200:0 $\mathrm{mg} \mathrm{kg}^{-1}$ de N-NO${ }_{3}^{-}$e N-NH${ }_{4}{ }^{+}$.

PALAVRAS-CHAVE: Sesamum indicum L.. Estresse salino. Nitrogênio. Tolerância. 


\section{REFERENCES}

ABBASDOKHT, H.; ASHRAFI, E.; TAHERI, S. Effects of different salt levels on germination and seedling growth of sesame (Sesamum indicum L.) cultivars. Technical Journal of Engineering and Applied Sciences, Montreal, v. 2, n. 10, p. 309-313, 2012.

ALVES, A. C.; JESUS, F. N.; SILVA, P. C. C.; SANTOS, A. R.; SOUZA, G. S. Diagnose nutricional de mudas de girassol submetidas a proporções de amônio e nitrato. Enciclopédia Biosfera, Goiânia, v. 9, n. 16, p. 723-731, 2013.

ALVES, A. N.; GHEYI, H. R.; UYEDA, C. A.; SOARES, F. A. L.; NOBRE, R. G.; CARDOSO, J. A. F. 2012. Uso de águas salinas e adubação nitrogenada no cultivo da mamoneira BRS - Energia. Revista Brasileira de Agricultura Irrigada, Fortaleza, v. 6, n. 2, p. 151-163, 2012. http://dx.doi.org/10.7127/rbai.v6n200218

ARAÚJO, J. L.; FAQUIN, V.; VIEIRA, N. M. B.; OLIVEIRA, M. V. C.; SOARES, A. A.; RODRIGUES, C. R.; MESQUITA, A. C. Crescimento e produção de arroz sob diferentes proporções de nitrato e de amônio. Revista Brasileira de Ciência do Solo, Viçosa, v. 36, n. 3, p. 921-930, 2012.http://dx.doi.org/10.1590/S010006832012000300022.

BAHRAMI H.; RAZMJOO J. Effect of salinity stress $(\mathrm{NaCl})$ on germination and early seedling growth of ten sesame cultivars (Sesamum indicum L.). International Journal of AgriScience, Dubendorf, v. 2, n. 6, p. 529537, 2012.

CAMPOS, C. N. S.; PRADO, R. M.; CAIONE, G.; NETO, A. J. L.; MINGOTTE, F. L. C. Silicon and excess ammonium and nitrate in cucumber plants. African Journal of Agricultural Research, Lagos, v. 11, n. 6, p. 276-283, 2016. http://dx.doi.org/10.5897/AJAR2015.10221.

CLAESSEN, M. E. C. (org.). Manual de métodos de análise de solo. 2.ed. rev. atual. Rio de Janeiro: Embrapa CNPS, 1997. 212p. Documentos, 1.

CORRÊA, M. J. P.; SANTOS, R. A. dos; FERNANDES, V. L. B.; ALMEIDA, F. C. G. Exportação de nutrientes pela colheita do gergelim (Sesamum indicum L.) cv. Jori. Revista Ciência Agronômica, Fortaleza, v. 26, n. $1-2$, p. 30-33, 1995.

CRUZ, J. L.; PELACANI, C. R.; COELHO, E. F.; CALDAS, R. C.; ALMEIDA, A. Q.; QUEIROZ, J. R. Influência da salinidade sobre o crescimento, absorção e distribuição de sódio, cloro e macronutrientes em plântulas de maracujazeiro-amarelo. Bragantia, Campinas, v. 65, n. 2, p. 275-284, 2006.

http://dx.doi.org/10.1590/S0006-87052006000200009.

FERREIRA, D. F. Sisvar: A computer statistical analysis system. Ciência e Agrotecnologia, Lavras, v. 35, n. 6, p. 1039-1042, 2011. http://dx.doi.org/10.1590/S1413-70542011000600001.

GARCIA, G. O.; FERREIRA, P. A.; MIRANDA, G. V.; NEVES, J. C. L.; MORAES, W. B.; SANTOS, D. B. Teores foliares dos macronutrientes catiônicos e suas relações com o sódio em plantas de milho sob estresse salino. Idesia, Árica, v. 25, n. 3, p. 93-106, 2007. http://dx.doi.org/10.4067/S0718-34292007000300010.

HOLZSCHUH, M. J.; BOHNEN, H.; ANGHINONI, I.; PIZZOLATO, T. M.; CARMONAF. C.; CARLOS, F. S. Absorção de nutrientes e crescimento do arroz com suprimento combinado de amônio e nitrato. Revista Brasileira de Ciência do Solo, Viçosa, v. 35, n. 4, p. 1357-1366, 2011. http://dx.doi.org/10.1590/S010006832011000400030.

LIMA, G. S. de; NOBRE, R. G.; GHEYI, H. R.; SOARES, L. A. dos A.; LACERDA, C. F. de. Effect of N fertilization on NPK content in castor bean under saline stress. African Journal of Agricultural Research, Lagos, v. 10, n. 33, p. 3319-3325, 2015. http://dx.doi.org/10.5897/AJAR2015.9552. 
LIMA, G. S. de; NOBRE, R. G.; GHEYI, H. R.; SOARES, L. A. dos A.; PINHEIRO, F. W. A.; DIAS, A. S. Crescimento, teor de sódio, cloro e relação iônica na mamoneira sob estresse salino e adubação nitrogenada. Comunicata Scientae, Bom Jesus, v. 6, n. 2, p. 212-223, 2015.

LIMA, M. S. R.; ROCHA, M. do S.; BELTRÃO, N. E. de M. Produção de sementes de gergelim. In: BELTRÃO, N. E. M.; FERREIRA, L. L.; QUEIROZ, N. L.; TAVARES, M. da S.; ROCHA, M. do S.; ALENCAR, R. D.; PORTO, V. C. N. (eds.). O gergelim e seu cultivo no semiárido brasileiro. Natal: IFRN, 2013, cap. 6, p. 85-101.

LUCENA, C. C. de; SIQUEIRA, D. L. de; MARTINEZ, H. E. P.; CECON, P. R. Efeito do estresse salino na absorção de nutrientes em mangueira. Revista Brasileira de Fruticultura, Jaboticabal, v. 34, n. 1, p. 29730.2012. http://dx.doi.org/10.1590/S0100-29452012000100039.

LUCENA, R. R. M.; NEGREIROS, M. Z.; MEDEIROS, J. F.; GRANEIRO, L. C.; MARROCOS, S. T. P. Crescimento e acúmulo de macronutrientes em melancia 'Quetzale' cultivada sob diferentes níveis de salinidade da água de irrigação. Revista Caatinga, Mossoró, v. 24, n. 1, p. 34-42, 2011.

NEVES, A. L. R.; LACERDA, C. F.; GUIMARÃES, F. V. A.; HERNANDEZ, F. F. F.; SILVA, F. B.; PRISCO, J. T.; GHEYI, H. R. Acumulação de biomassa e extração de nutrientes por plantas de feijão-de-cordas irrigadas com água salina em diferentes estádios de desenvolvimento. Ciência Rural, Santa Maria, v. 39, n. 3, p. 758-765, 2009. http://dx.doi.org/10.1590/S0103-84782009005000014.

NOBRE, R. G.; LIMA, G. S.; GHEYI, H. R.; SOARES, L. A. A.; SILVA, A. O. Crescimento, consumo e eficiência do uso da água pela mamoneira sob estresse salino e nitrogênio. Revista Caatinga, Mossoró, v. 27, n. 2, p. $148-158,2014$.

NOBRE, R. G.; SOARES, L. A. A.; GHEYI, H. R.; LIMA, G. S.; LOURENÇO, G. S.; SOARES, S.S. Acúmulo de NPK e sódio a mamoneira sob estresse salino e adubação nitrogenada. Revista Brasileira de Engenharia Agrícola e Ambiental, Campina Grande, v. 17, n. 10, p. 1066-1073, 2013. http://dx.doi.org/10.1590/S1415-43662013001000007.

NOBRE, R. G.; GHEYI, H. R.; SOARES, F. A. L.; CARDOSO, J. A. F. Produção de girassol sob estresse salino e adubação nitrogenada. Revista Brasileira de Ciência do Solo, Viçosa, v. 35, n. 3, p. 929-937, 2011. http://dx.doi.org/10.1590/S0100-06832011000300027.

NOVAIS, R. F.; NEVES, J. C. L.; BARROS, N. F. Ensaio em ambiente controlado. In: OLIVEIRA, A. J. (ed.) Métodos de pesquisa em fertilidade do solo. Brasília: Embrapa SEA,1991. p. 189-25.

OLIVEIRA, F. A.; CAMPOS, M. S.; OLIVEIRA, F. R. A.; OLIVEIRA, M. K. T.; MEDEIROS, J. F.; MELO, T. K. Desenvolvimento e concentração de nitrogênio, fósforo e potássio no tecido foliar da berinjela em função da salinidade. Revista Brasileira de Ciências Agrárias, Recife, v. 6, n. 1, p. 37-45, 2011.

http://dx.doi.org/10.5039/agraria.v6i1a807.

PEDROTTI, A.; CHAGAS, R. M.; RAMOS, V. C.; PRATA, A. P. N.; LUCAS, A. A. T.; SANTOS, P. B. Causas e consequências dos processos de salinização dos solos. Revista Eletrônica em Gestão, Educação e Tecnologia Ambiental, Santa Maria, v. 19, n. 2, p. 1308-1324, 2015.

QUEIROGA, V. P.; BORBA, F. G.; ALMEIDA, K. V.; SOUSA, W. J. B.; JERÔNIMO, J. F.; QUEIROGA, D. A. N. Qualidade fisiológica e composição química das sementes de gergelim com distintas cores. Revista Agro@mbiente, Boa Vista, v. 4, n. 1, p. 27-33, 2010.

RHOADES, J. D.; KANDIAH, A.; MASHALI, A. M. Uso de águas salinas para produção agrícola. 1. ed. Campina Grande: UFPB. 2000. 117 p. (Estudos da FAO. Irrigação e Drenagem). 
ROCHA, J. G.; FERREIRA, L. M.; TAVARES, O. C. H.; SANTOS, A. M.; SOUZA, S. R. Cinética de absorção de nitrogênio e acúmulo de frações solúveis nitrogenadas e açucares em girassol. Pesquisa Agropecuária Tropical, v. 44, n. 4, p. 381-390, 2014. http://dx.doi.org/10.1590/S1983-40632014000400009.

SILVA, E. M da; SILVEIRA, J. A. G.; FERNANDES, C. R. R.; DUTRA, A. T. B.; ARAGÃO, R.M de. Acúmulo de íons e crescimento de pinhão-manso sob diferentes níveis de salinidade. Revista Ciência Agronômica, Fortaleza, v. 40, n. 2, p. 240-246, 2009.

SILVA, F. C. Manual de análises químicas de solos, plantas e fertilizantes. Brasília: Embrapa Comunicação para Transferência de Tecnologia, 1999. 370p.

SILVA, P. C. C.; COUTO, J. L.; SANTOS, A. R. Efeito dos íons amônio e nitrato no desenvolvimento do girassol em solução nutritiva. Revista da FZVA, Uruguaiana, v. 17, n. 1, p. 104-114, 2010.

SOARES, L. A. dos A.; NOBRE, R. G.; GHEYI, H. R.; LIMA, G. S. de; SILVA, A. O. da; SOARES, S. da S. Componentes de crescimento da mamoneira cultivada com águas salinas e doses de nitrogênio. Irriga, Botucatu, Edição Especial: 40-54, 2012.

SOUSA, A. E. C., LACERDA, C. F. de; GHEYI, H. R., SOARES, F. A. L., UYEDA, C. A. Teores de nutrientes foliares e respostas fisiológicas em pinhão manso submetido a estresse salino e adubação fosfatada. Revista Caatinga, Mossoró, v. 25, n. 2, p. 144-152, 2012.

SOUSA, G. G.; LACERDA, C. F.; CAVALCANTE, L. F.; GUIMARÃES, F. V. A.; BEZERRA, M. E. J.; SILVA, G. L. Nutrição mineral e extração de nutrientes de planta de milho irrigada com água salina. Revista Brasileira de Engenharia Agrícola e Ambiental, Campina Grande, v. 14, n. 11, p. 1143-1151. http://dx.doi.org/10.1590/S1415-43662010001100003.

SUASSUNA, J. F. Tolerância de genótipos de gergelim ao estresse salino. 2013. 126 f. Tese (Doutorado em Engenharia Agrícola: Área de Concentração em Irrigação e Drenagem) - Universidade Federal de Campina Grande, Campina Grande, 2013.

TRENKEL, M. E. Improving fertilizer use efficiency: Controlled-release and stabilized fertilizers in agriculture. Paris: IFIA, $1997.151 \mathrm{p}$

WILLADINO, L.; GOMES, E. W. F.; SILVA, E. F. F.; MARTINS, L. S. S.; CAMARA, T. R. Efeito do estresse salino em genótipos tetraplóides de bananeira. Revista Brasileira de Engenharia Agrícola e Ambiental, Campina Grande, v. 15, n. 1, p. 53-59, 2011. http://dx.doi.org/10.1590/S1415-

43662011000100008. 